\title{
Hubungan Pengetahuan Kesehatan Gigi dan Mulut dengan Karies Gigi pada Mahasiswa Baru Fakultas Kedokteran Gigi Uni- versitas Jember Tahun Akademik 2016/2017 (Correlation of Oral Health Knowledge with Dental Caries in First Grade Dentistry Students of Jember University Academic Year 2016/2017)
}

\author{
Galuh Cita Sari Rahtyanti ${ }^{1},$. Hestieyonini Hadnyanawati ${ }^{2}$, Erawati Wulandari ${ }^{3}$ \\ ${ }^{1}$ Fakultas Kedokteran Gigi Universitas Jember \\ ${ }^{2}$ Bagian Ilmu Kedokteran Gigi Masyarakat Fakultas Kedokteran Gigi Universitas Jember \\ ${ }^{3}$ Bagian Konsevasi Gigi Fakultas Kedokteran Gigi Universitas Jember \\ Jl. Kalimantan 37 Jember 68121 \\ E-mail: galuhrahtyanti@yahoo.com
}

\begin{abstract}
Background: One of major oral health problem found in oral cavity is dental caries. Several factors can induce dental caries such as economical factors, excessive high sugar content foods consumption, and neglect of oral hygiene due to lack of knowledge in how important is teeth and mouth maintenance. Objective: To analyzed correlation between oral health knowledge and dental caries in first grade Dentistry students of Jember University Academic Year 2016/2017. This research used cross sectional approach with total respondents of 119 students. The assessment of oral health knowledge was done by questionnaire and DMF-T index was used to evaluated dental caries in oral cavity. Results and Conclusion: The majority of oral health knowledge distribution in first grade dentistry students of Jember University academic year 2016/2017 was 106 students (89,1\%) in good category and DMF-T score of 53 students or $44.5 \%$ in very high category. The results of data analyzed by Spearman correlation test could be concluded that there was a significant relation between dental caries and oral health knowledge of first grade Dentistry students Jember University academic year 2016/2017 with moderate correlation strength $(-0.460)$.
\end{abstract}

Keywords : Dental caries, First grade dentistry students, Oral health knowledge

\begin{abstract}
Abstrak
Latar Belakang: Karies adalah penyakit yang paling banyak dijumpai di rongga mulut, sehingga merupakan masalah utama kesehatan gigi dan mulut. Karies dapat disebabkan oleh beberapa faktor diantaranya adalah ekonomi, konsumsi makanan dengan kandungan gula tinggi dalam jumlah besar serta sikap mengabaikan kebersihan gigi dan mulut karena kurangnya pengetahuan akan pentingnya pemeliharaan gigi dan mulut. Tujuan penelitian: Menganalisis hubungan pengetahuan kesehatan gigi dan mulut dengan karies gigi pada mahasiswa baru Fakultas Kedokteran Gigi Universitas Jember Tahun Akademik 2016/2017. Penelitian menggunakan pendekatan cross sectional dengan jumlah responden 119 mahasiswa. Pengetahuan kesehatan gigi dan mulut dinilai menggunakan kuisioner dan karies gigi dinilai menggunakan indeks DMF-T. Hasil dan Simpulan: Distribusi pengetahuan kesehatan gigi dan mulut Mahasiswa baru Fakultas Kedokteran Gigi Universitas Jember tahun akademik 2016/2017 paling banyak berada pada kategori baik yaitu sebanyak 106 (89,1\%). Mahasiswa baru paling banyak memiliki nilai DMF-T pada kategori sangat tinggi yaitu sebanyak 53 orang atau $44,5 \%$. Hasil analisis data menggunakan uji korelasi Spearman dapat disimpulkan bahwa terdapat hubungan signifikan karies gigi terhadap pengetahuan kesehatan gigi dan mulut mahasiswa baru Fakultas Kedokteran Gigi Universitas Jember tahun akademik 2016/2017 dengan kekuatan korelasi sedang $(-0,460)$.
\end{abstract}

Kata kunci : Karies gigi, Mahasiswa Baru Fakultas Kedokteran Gigi, Pengetahuan kesehatan gigi dan mulut 


\section{Pendahuluan}

Kesehatan gigi dan mulut khususnya karies gigi dapat dipengaruhi oleh beberapa faktor diantaranya adalah konsumsi makanan dengan kandungan gula tinggi seperti cokelat, permen, jelli dan minuman bersoda dalam jumlah besar serta sikap mengabaikan kebersihan gigi dan mulut.[1] Kriteria umum yang mempengaruhi sikap menjaga kesehatan gigi seseorang atau komunitas adalah pengetahuan, kepercayaan, kemampuan ekonomi, waktu, dan pengaruh dari orang-orang disekelilingnya. Tingkat pengetahuan merupakan salah satu hal penting yang menyebabkan tingginya kejadian karies. Pengetahuan yang baik mempengaruhi perilaku kesehatan dalam meningkatkan kesehatan khususnya kesehatan gigi dan mulut sebaliknya pengetahuan yang kurang mengenai pentingnya pemeliharaan gigi dan mulut dapat menyebabkan timbulnya sikap mengabaikan kebersihan gigi dan mulut.[2]

Karies gigi merupakan salah satu penyakit yang paling banyak dijumpai di rongga mulut, sehingga merupakan masalah utama kesehatan gigi dan mulut. Hal ini didukung data Bulan Kesehatan Gigi Nasional (BKGN) ke V (lima), 12 September - 19 November 2014 yang menunjukkan jumlah karies (gigi berlubang) penduduk Indonesia terhitung sebesar 93.998.727 jiwa.[3] Jumlah yang sangat tinggi dalam status kesehatan masyarakat Indonesia. Prevalensi karies gigi penduduk Indonesia juga mengalami kenaikan, yaitu $43,4 \%$ pada tahun 2007 menjadi 53,2\% pada tahun 2013.[4];[5]

Riset Kesehatan Dasar tahun 2013 menunjukkan indeks DMF-T penduduk Indonesia mencapai 4,6 dengan nilai D-T (Decayed) sebesar 1,6; M-T (Missing) sebesar 2,9 dan F-T (Filling) sebesar 0,08 yang berarti terdapat 460 buah gigi karies per 100 orang.[5] Penelitian yang dilakukan oleh Tjahja, dkk mengenai gambaran karies gigi permanen di beberapa puskesmas di Kabupaten Bandung selama 10 bulan pada tahun 2002 pada usia 19-34 tahun memiliki DMF-T sebesar 5,55. Data tersebut membuktikan adanya karies gigi pada kelompok usia produktif.[6]

Mahasiswa baru (freshman) adalah mahasiswa pada masa tahun pertama di universitas. Mahasiswa tahun pertama umumnya berusia antara 17 sampai 20 tahun.[7] Mahasiswa kedokteran gigi merupakan penyedia layanan kesehatan gigi dan mulut di masa mendatang dan akan bertanggung jawab ter- hadap edukasi kesehatan gigi dan mulut masyarakat.[8] Penelitian yang dilakukan oleh Ahamed,dkk pada mahasiswa kedokteran gigi tingkat pertama dan kedua serta mahasiswa klinik kedokteran gigi yang berusia 18 tahun-25 tahun di India menunjukkan mahasiswa tingkat pertama memiliki nilai rata-rata pengetahuan kesehatan gigi dan mulut terendah dan terus meningkat secara signifikan pada tingkat berikutnya. Mahasiswa tingkat pertama memiliki nilai pengetahuan kesehatan gigi dan mulut 4,979; mahasiswa tingkat 2 memiliki nilai 5,325; nilai 7,432 pada tingkat ke 3 dan nilai 8,107 pada tingkat ke 4 . Kondisi ini menggambarkan perbedaan pengalaman yang dimiliki oleh mahasiswa kedokteran gigi sesuai lama masa studi.[9]

Hasil penelitian Radiah pada mahasiswa asal kota Ternate di kota Manado menunjukkan indeks D (Decayed) berjumlah 175 (61,4\%), M (Missing) berjumlah $76(26,7 \%), \mathrm{F}$ (Filling) berjumlah $34(11,9 \%)$ dan jumlah indeks DMF-T rata-rata seluruh responden adalah 3,1. [10] Penelitian Wyne, dkk terhadap mahasiswa kedokteran gigi di Riyadh menunjukkan nilai rata-rata DMF-T mencapai 7,97.[11]

Hasil penelitian mengenai hubungan tingkat pengetahuan kesehatan gigi dan mulut dengan karies yang telah dilakukan oleh Annisa menunjukkan terdapat hubungan signifikan antara pengetahuan kesehatan gigi dan mulut dengan karies gigi.[12] Penelitian lain yang dilakukan oleh Rosdewi terhadap hubungan tingkat pengetahuan kesehatan gigi dan mulut dengan karies gigi menunjukkan hasil prevalensi karies $63,2 \%$ pada tingkat pengetahuan kurang dan $16,2 \%$ pada responden dengan tingkat pengetahuan baik.[13]

Karies gigi masyarakat Indonesia yang tinggi dan penelitian-penelitian yang menunjukkan adanya hubungan antara pengetahuan kesehatan gigi dan mulut dengan angka karies gigi mendorong penulis untuk meneliti hubungan pengetahuan kesehatan gigi dan mulut dengan karies gigi pada mahasiswa Universitas Jember, khususnya mahasiswa baru Fakultas Kedokteran Gigi Universitas Jember tahun akademik 2016/2017.

\section{Metode Penelitian}

Jenis penelitian ini adalah penelitian observasional analitik dengan pendekatan cross sectional. Penelitian ini dilakukan pada seluruh mahasiswa baru Fakultas Kedokteran Gigi Uni- 
versitas Jember tahun akademik 2016/2017 yang telah bersedia menandatangani informed consent.

Pemeriksaan karies mahasiswa baru dilakukan di ruang oral diagnosa Rumah Sakit Gigi dan Mulut Fakultas Kedokteran Gigi Universitas Jember pada bulan Desember 2016 sampai Januari 2017. Mahasiswa baru diperiksa secara visual kondisi dalam rongga mulutnya setelah ditempatkan pada dental chair dengan penerangan cukup dengan bantuan sonde dan kaca mulut dari sisi kiri posterior rahang bawah lalu ke anterior dan posterior kanan rahang bawah, selanjutnya gigi posterior kiri rahang atas lalu ke anterior dan posterior kanan rahang atas. Kondisi dalam rongga mulut yang diperiksa adalah pemeriksaan decayed (lubang atau karies), pemeriksaan gigi missing (hilang) dan pemeriksaan filling (tambalan). Pengisian kuisioner dilakukan pada hari terpisah di ruang kuliah Fakultas Kedokteran Gigi Universitas Jember. Kuisioner berisi 20 pertanyaan mengenai karies gigi, penyakit gusi dan perilaku menjaga kesehatan gigi dan mulut.

Data hasil penelitian dilakukan penghitungan untuk kemudian dianalisis menggunakan uji normalitas Kolmogorov-Smirnov dan dilanjutkan dengan uji korelasi Spearman untuk mengetahui hubungan pengetahuan kesehatan gigi dan mulut dengan karies gigi pada mahasiswa baru Fakultas Kedokteran Gigi Universitas Jember tahun akademik 2016/2017.

\section{Hasil}

Penelitian tentang hubungan pengetahuan kesehatan gigi dan mulut dengan karies gigi pada seluruh mahasiswa baru Fakultas Kedokteran Gigi Universitas Jember tahun akademik 2016/2017 sejumlah 119 orang didominasi oleh jenis kelamin perempuan yaitu 105 orang $(89,2 \% /)$ dengan jumlah mahaiswa laki-laki hanya mencpai $11,8 \%$ atau sebanyak 14 orang. Berkaitan dengan usia, mahasiswa baru Fakultas Kedokteran Gigi Universitas Jember angkatan 2016 sebanyak 119 orang berusia 16-20 tahun dan paling banyak memiliki usia 18 tahun yaitu 77 orang $(64,7 \%)$ dan jumlah terendah pada usia 20 tahun yaitu $1(0,8 \%)$. Pengetahuan kesehatan gigi dan mulut mahasiswa baru pada seluruh usia di kelompokkan menjadi tiga kriteria yaitu baik, sedang dan rendah.
Hasil penilaian kuesioner mengenai pengetahuan kesehatan gigi dan mulut pada mahasiswa baru Fakultas Kedokteran Gigi Universitas Jember tahun akademik 2016/2017 dapat dilihat pada Tabel 1.

Tabel 1. Distribusi kriteria kuesioner pengetahuan kesehatan gigi dan mulut pada mahasiswa baru Fakultas Kedokteran Gigi Universitas Jember

\begin{tabular}{crr}
\hline Kriteria & Jumlah & Persentase (\%) \\
\hline Rendah & 0 & $0 \%$ \\
Sedang & 13 & $10,9 \%$ \\
Baik & 106 & $89,1 \%$ \\
\hline Total & 119 & $100 \%$ \\
\hline
\end{tabular}

Hasil data berdasarkan Tabel 1. tidak ada seorangpun mahasiswa yang memiliki tingkat pengetahuan kesehatan gigi dan mulut yang rendah. Mayoritas dari mahasiswa $(89,1 \%)$ yaitu 106 orang memiliki tingkat pengetahuan kesehatan gigi dan mulut yang baik, sisanya berada dalam kategori sedang (10,9\%). Hal ini menunjukkan mayoritas mahasiswa baru memiliki pengetahuan pada kriteria baik. Berbeda dengan pengetahuan kesehatan gig dan mulut, indeks DMF-T yang menggambarkan status karies gigi dibagi menjadi 5 kriteria sesuai dengan kriteria WHO yaitu sangat rendah, rendah, sedang, tinggi dan sangat tinggi.

Hasil penelitian karies gigi mahasiswa baru berdasarkan kriteria DMF-T dijelaskan pada Tabel 2.

Tabel 2. Distribusi kriteria DMF-T pada mahasiswa baru Fakultas Kedokteran Gigi Universitas Jember

\begin{tabular}{lrr}
\hline Kriteria & Jumlah & Persentase (\%) \\
\hline Sangat Rendah & 9 & $7,6 \%$ \\
Rendah & 11 & $9,2 \%$ \\
Sedang & 25 & $21 \%$ \\
Tinggi & 21 & $17,6 \%$ \\
Sangat Tinggi & 53 & $44,5 \%$ \\
\hline Total & 119 & $100 \%$ \\
\hline
\end{tabular}

Hasil penilaian menunjukkan mayoritas mahasiswa baru memiliki nilai indeks DMF-T pada kriteria sangat tinggi yaitu sebanyak 53 orang $(17,6 \%)$ dan jumlah paling sedikit berada pada kriteria sangat rendah yaitu 9 orang $(7,6 \%)$.

Pada penelitian ini dilakukan uji normalitas untuk menentukan jenis distribusi data hasil penelitian menggunakan uji Kolmogrov-Smirnov karena besar sampel penelitian lebih dari 50 . 
Hasil analisa data menggunakan uji KolmogrovSmirnov didapat nilai $p=0,006$ untuk pengetahuan kesehatan gigi dan mulut dan nilai $p=0,170$ untuk DMF-T yang menunjukkan data berdistribusi tidak normal.

Data hasil kuisioner pengetahuan kesehatan gigi dan mulut memiliki distribusi tidak normal sehingga untuk melihat adanya hubungan antar variabel dilakukan menggunakan uji korelasi Spearman Hasil analisa uji korelasi Spearman pada hubungan pengetahuan kesehatan gigi dan muklut dengan karies gigi pada mahasiswa baru Fakultas Kedokteran Gigi Universitas Jember Tahun akademik 2016/2017 menunjukkan nilai signifikansi $0,00 \quad(p<005)$ yang berarti terdapat hubungan antara karies gigi dengan pengetahuan kesehatan gigi dan mulut. Nilai koefisien korelasi sebesar $-0,460$ yang menujukkan adanya hubungan negatif dengan kekuatan korelasi sedang antara karies gigi dengan pengetahuan kesehatan gigi dan mulut

\section{Pembahasan}

Status karies gigi adalah suatu keadaan yang menggambarkan prosentase dan derajat keparahan penyakit gigi masyarakat, berdasarkan pengalaman karies yang pernah terjadi pada setiap individu. Pengalaman karies (caries experience) gigi permanen biasanya dinyatakan dengan indeks DMF-T sebagai indikator yang digunakan untuk menentukan prevalensi karies dan insiden karies di masyarakat.[14] Survey atau penelitian tentang status karies gigi bertujuan untuk melihat karakteristik pengalaman karies di masyarakat dan menjelaskan sejauh mana efek penyakit gigi terhadap suatu populasi pada suatu periode tertentu.[15]

Penelitian ini dilakukan untuk mengetahuai hubungan pengetahuan kesehatan gigi dan mulut dengan karies gigi mahasiswa baru Fakultas Kedokteran Gigi Universitas Jember angkatan 2016 dengan menggunakan pendekatan cross-sectional. Pemeriksaan status karies gigi dan tingkat pengetahuan gigi dan mulut dilakukan dalam waktu yang bersamaan dan hanya dilakukan satu kali saja. Usia dominan mahasiswa baru adalah 18 tahun-19 tahun dengan persentase tertinggi pada kelompok usia 18 tahun sebanyak 77 orang $(64,7 \%)$ dengan mayoritas mahasiswa perempuan sebanyak 105 orang $(89,2 \%)$ dan mahasiswa laki-laki hanya sejumlah 14 orang $(11,8 \%)$.
Pengetahuan kesehatan gigi dan mulut mahasiswa baru Fakultas Kedokteran Gigi Universitas Jember tahun akademik 2016/2017 adalah baik. Hal ini terlihat dari dominasi perolehan persentase kategori baik sebesar $89,01 \%$, sedangkan sisanya berada pada tingkat kategori sedang 10,09\%. Hal ini menunjukkan bahwa mahasiswa baru telah berhasil dalam memperoleh, mengingat dan memahami informasi dari apa yang dilihat dan didengar mengenai karies gigi serta telah mengetahui cara menjaga kebersihan gigi yang baik. Pendidikan sangat berhubungan erat dengan pengetahuan, terutama pengetahuan tentang kesehatan. Mahasiswa baru merupakan mahasiswa yang baru masuk ke perguruan tinggi setelah lulus dari sekolah menengah atas. Penelitian yang telah dilakukan oleh Gede,dkk pada murid SMAN 9 Manado juga menunjukkan $95 \%$ memiliki tingkat pengetahuan yang baik.[16] Seseorang yang memiliki pendidikan tinggi diasumsikan memiliki pengetahuan yang baik. Semakin tinggi pendidikan formal seseorang maka semakin baik pengetahuan dan sikap tentang kesehatan yang memengaruhi prilaku hidup sehat, dengan demikian juga semakin mudah dalam memperoleh pekerjaan dan semakin banyak penghasilan yang diperoleh untuk memenuhi kebutuhan kesehatan.[17]

Distribusi status karies gigi serta tingkat pengetahuan kesehatan gigi dan mulut menunjukkan nilai yang hampir sama dan berada pada kriteria sangat tinggi. Periode pubertas (remaja) usia antara 14-20 tahun umumnya sebagian besar rentan terhadap karies gigi karena terjadi perubahan hormonal yang dapat menimbulkan pembengkakan gusi, sehingga kebersihan mulut menjadi kurang terjaga. Mahasiswa baru pada peneitian ini berusia antara 16-20 tahun dengan mayoritas berada pada uia 18 tahun sehingga masih berrada dalam periode pubertas, hal inilah yang menyebabkan persentase karies lebih tinggi.[18]

Besarnya hubungan dan arah hubungan korelasi antara pengetahuan kesehatan gigi dan mulut terhadap karies gigi pada mahasiswa baru Fakultas Kedokteran Gigi Universitas Jember tahun akademik 2016/2017 dilakukan menggunakan uji korelasi Spearman dengan terlebih dulu dilakukan uji normalitas Kolmorov-Smirnov. Hasil uji korelasi Spearman menunjukkan bahwa terdapat hubungan signifikan antara karies gigi dengan pengetahuan kesehatan gigi dan mulut mahasiswa baru dalam kategori sedang dengan koefisien korelasi sebesar -0,046 yang berarti semakin tinggi nilai DMF-T maka tingkat penget- 
ahuan kesehatan gigi dan mulut akan semakin rendah.

Pada penelitian ini ditemukan bahwa
sebanyak 62 orang memiliki tingkat pengetahuan baik namun memiliki kriteria nilai indeks DMF-T yang tinggi dan sangat tinggi. Hal ini disebabkan karena pengetahuan yang tinggi tidak optimal diterapkan dalam mendorong perilaku pemeliharaan kebersihan gigi dan mulut sehari-hari walaupun sudah memiliki pengetahuan kesehatan gigi dan mulut yang baik, selain itu pengetahuan yang diterima tidak semua bisa dipraktikkan karena terdapat faktorfaktor pendukung lain yang dapat mempengaruhi pengetahuan misalnya peran orangtua, guru, faktor lingkungan, sosial ekonomi, dan faktor lainnya. Pendidikan kesehatan gigi dan mulut dapat menghasilkan perubahan atau peningkatan pengetahuan, sedangkan peningkatan pengetahuan belum tentu akan berpengaruh langsung terhadap status karies gigi.[19] Menurut Warni, pengetahuan yang baik belum tentu tindakan yang dilakukan baik pula. Hal tersebut karena pengetahuan sebatas perilaku tertutup, artinya masih terbatas dalam bentuk perhatian perasaan dan persepsi. Tindakan sendiri termasuk perilaku terbuka, artinya telah dilakukan atau telah diterapkan.[20] Kemungkinan lain adalah proses karies gigi telah terjadi lama sebelum mahasiswa baru memasuki perguruan tinggi dan mendapat pengetahun yang lebih baik mengenai kesehatan gig dan mulut [21].

\section{Simpulan dan Saran}

Kesimpulan berdasarkan hasil penelitian dan pembahasan yang telah diuraikan adalah mahasiswa baru Fakultas Kedokteran Gigi Universitas Jember tahun akademik 2016/2017 memiliki distribusi pengetahuan kesehatan gigi dan mulut paling banyak pada kategori baik yaitu sebanyak $106 \quad(89,1 \%)$ dengan nilai DMF-T pada kategori sangat tinggi yaitu sebanyak 53 orang atau 44,5\%. Hasil analisis data menggunakan uji korelasi Spearman dapat disimpulkan bahwa terdapat hubungan signifikan karies gigi terhadap pengetahuan kesehatan gigi dan mulut mahasiswa baru Fakultas Kedokteran Gigi Universitas Jember tahun akademik 2016/2017 dengan kekuatan korelasi sedang $(-0,460)$.

Saran pada penelitian ini adalah perlu dilakukan penelitian penelitian lebih lanjut dan meluas untuk memperoleh status karies gigi yang ada pada mahasiswa di Universitas Jember serta penelitian lanjutan mengenai karies gigi dengan mempertimbangkan faktorfaktor lain yang tidak diteliti dalam penelitian ini seperti cara menyikat gigi, status kebersihan mulut dan kebiasaan buruk. Bagi mahasiswa baru diharapkan dapat meningkatkan kesadaran akan kesehatan gigi dan mulut sebagai suatu tindakan preventif terhadap terjadinya karies misalnya dengan memeriksakan gigi ke dokter gigi setiap 6 bulan sekali.

\section{Daftar Pustaka}

[1] Kaur, R., Kataria, H., Kumar, S., dan Kaur, G. 2010. "Caries Experience among Females aged 16-21 in Punjab, India and its Relationship with Lifestyle and Salivary HSP70 Levels". Eur J Dent, 4 (3): 303-308.

[2] Kawuryan, U. 2008. Hubungan pengetahuan tentang kebersihan gigi dan mulut dengan kejadian karies anak SDN Kleco II kelas V dan VI Laweyan Surakarta. Skripsi. Surakarta: Universitas Muhammadiyah Surakarta. hal.33.

[3] Kementerian Riset, Teknologi dan Pendidikan Tinggi RI. 2013-2016. Pangkalan Data Pendidikan Tinggi. Jakarta: Kementerian Riset, Teknologi dan Pendidikan Tinggi.

[4] Badan Penelitian dan Pengembangan Kesehatan Departemen Kesehatan Republik Indonesia. 2008. Riset Kesehatan Dasar (RISKESDAS) 2007. Badan Penelitian dan Pengembangan Kesehatan Departemen Kesehatan Republik Indonesia

[5] Badan Penelitian dan Pengembangan Kesehatan Departemen Kesehatan Republik Indonesia. 2013. Riset Kesehatan Dasar (RISKESDAS) 2013. Badan Penelitian dan Pengembangan Kesehatan Departemen Kesehatan Republik Indonesia

[6] Tjahja I. N., Sintawati F. X., dan Yovita T. A. 2006. Gambaran Karies Gigi Permanen di Beberapa Puskesmas Kota dan Kabupaten Bandung, Sukabumi, serta Bogor Tahun 2002. Media Litbang Kesehatan. Vol. 17 (4): 26-31. 
[7] Sari, R.P., Rezeki A.T, dan Mujab M,A. 2006. Pengungkapan Diri Mahasiswa Tahun Pertama Universitas Diponegoro Ditinjau dari Jenis Kelamin dan Harga Diri. Jurnal Psikologi Universitas Diponegoro 3 (2): 11-25

[8] Shirazi, U., Naz .F, dan Yousuf M. 2013. DMF-T Index Among Dental Undergraduates Of Lahore Medical And Dental College In Different Professional Years Of Dentistry. Pakistan Oral \& Dental Journal 33 ( 1): 156

[9] Ahamed, Moyin, Punathil, Patil, Kale dan Pawar. 2015. Evaluation of The Oral Health Knowledge, Attitude and Behavior of The Preclinical and Clinical Dental Students. Journal of International Oral Health Vol. 7 (6): $65-70$

[10] Radiah. 2013. Gambaran Status Karies dan Pola Pemeliharaan Kesehatan Gigi dan Mulut pada Mahasiswa Asal Ternate di Manado. Jurnal e-Gigi. Vol.1 (1): 45-51

[11] Wyne, A.H., Choham A.N., Al-Motairy E.A.A., Al Gezzy S.A. 2007. Dental Caries and Oral Hygiene in Male Dental Students of King Saud University College of Dentistry, Riyadh. Pakistan Oral \& Dental Journal 27 (2): 219-222

[12] Annisa, A. 2014. Perbedaan Prevalensi Karies Dan Tingkat Pengetahuan Kesehatan Gigi Pada Murid Sekolah Dasar Usia 9-10 Tahun Yang Memiliki UKGS dengan Yang Tidak Memiliki UKGS Di Kecamatan Kolaka Tahun 2014. Makassar: Skripsi Sarjana pada FKG Universitas Hasanudin.

[13] Rosdewi, N. N. 2015. Hubungan Tingkat Pengetahuan Siswa Tentang Karies Gigi Dan Kebiasaan Menggosok Gigi Dengan Kejadian Karies Gigi Siswa Kelas 3 dan
Kelas 4 SDN Caturtunggal 4 Depok Sleman Yogyakarta Tahun 2013. Jurnal Medika Respati Vol. 10 (2): 59-67.

[14] Jovianti, T.A. 2010. Pengaruh Kebiasaan Menyikat Gigi terhadap Status Pengalaman Karies Riskesdas 2007. FKM UI:Thesis.

[15] Shulman, J.D., dan Cappelli, D.P., 2008, Epidemiology of Dental Caries: Prevention in Clinical Oral Health Care. United State: Mosby Elsevier. hal: 7.

[16] Gede, Pandelaki dan Mayan. 2013. Hubungan Pengetahuan Kebersihan Gigi dan Mulut Dengan Status Kebersihan Gigi Dan Mulut Pada Siswa Sma Negeri 9 Manado. Jurnal e-GiGi (eG), Vol.1 (2): 8488.

[17] Tulangow, Mariati dan Mintjelungan. 2013. Gambaran Status Karies Murid Sekolah Dasar Negeri 48 Manado Berdasarkan Status Sosial Ekonomi Orang Tua. Jurnal e-GiGi (eG), Vol. 1 (2): 85-93.

[18] Tarigan, R. 2013. Karies Gigi, Ed. 2. Jakarta: EGC. hal. 22.

[19] Notoatmodjo, S. 2007. Kesehatan Masyarakat IImu dan Seni. Jakarta: PT. Rineka Cipta. hal.106-107: 142: 262-263

[20.] Warni, L. 2009. Hubungan Perilaku Murid Sd Kelas V dan VI Pada Kesehatan Gigi dan Mulut Terhadap Status Karies Gigi di Wilayah Kecamatan Delitua Kabupaten Deli Serdang. Medan: Thesis Magister IImu Kesehatan Masyarakat Universitas Sumatera Utara.

[21] Dabrowska, E., Letko R. dan Balunowska M. 2006. Assessment of Dentition Status and Oral Hygiene in First Year Students, Medical University of Bialystok. Advance in Medical Science Vol. 51: 105 